\title{
Farklı düzeylerdeki sulama uygulamalarının kinoa bitkisi üzerine etkileri II: Vejetatif gelişim, verim ve kalite parametreleri
}

\section{The effects of different levels of irrigation practices on quinoa II: Vegetative growth, yield and quality parameters}

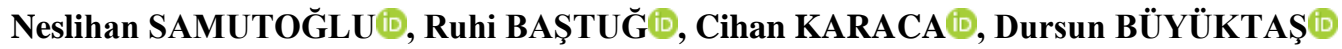 \\ Akdeniz Üniversitesi, Ziraat Fakültesi, Tarımsal Yapılar ve Sulama Bölümü, Antalya, Türkiye \\ Sorumlu yazar (Corresponding author): R. Baştuğ, e-posta (e-mail): rbastug@akdeniz.edu.tr \\ Yazar(lar) e-posta (Author e-mail): neslihansamutoglu@gmail.com, cihankaraca@akdeniz.edu.tr, dbuyuktas@akdeniz.edu.tr
}

\section{MAKALE BİLGİSİ}

Alınış tarihi 07 Mayıs 2020

Düzeltilme tarihi 21 Eylül 2020

Kabul tarihi 28 Eylül 2020

\section{Anahtar Kelimeler:}

Verim

Stoma iletkenliği

Klorofil

Protein içeriği

Yağ asitleri

\section{$\ddot{O} \mathbf{Z}$}

$\mathrm{Bu}$ çalışmada, farklı düzeylerdeki sulama uygulamalarının Akdeniz iklim koşullarında yetiştirilen kinoa bitkisinin vejetatif gelişim, verim ve kalite parametreleri üzerine etkilerinin belirlenmesi amaçlanmıştır. Araştırma drenaj tipi lizimetre sisteminde, kumlu tın bünyeli toprakta, 2017 yılında, Titicaca (Q-52) kinoa (Chenopodium quinoa Willd.) çeşidi ile yürütülmüștür. Araștırmada tam sulama (TS), sırasıyla $\% 75,50$ ve 25 oranında kisıntılı sulama (KS75, KS50, KS25) ve susuz (SZ) konuları tesadüf blokları deneme deseninde üç tekerrürlü olarak ele alınmıştır. TS konusuna 7 günde bir toprak su içeriğini tarla kapasitesine getirecek kadar, kısıntılı sulama konularına ise belirtilen kısıntı oranları dikkate alınarak sulama suyu uygulanmıştır. Deneme sonunda sulama konularında dane verimi, bitki boyu, stoma iletkenliği değerleri sirasılyla 243.0 (SZ)- 295.0 (TS) $\mathrm{kg} \mathrm{da}^{-1}$; bi 93.5 (SZ)-103.2 (TS) $\mathrm{cm} ; 252.4$ (SZ)-319.8 (TS) mmol m $\mathrm{m}^{-2} \mathrm{~s}^{-1}$, klorofil indeks içeriği mevsim içinde 2.8-57.0 arasında değişmiştir. Dane verimi, bitki boyu, stoma iletkenliği değerleri sulama konularında, yaprak klorofil içeriği değerleri ise mevsim içinde istatistiksel açıdan önemli farklılıklar $(\mathrm{p}<0.01)$ göstermiştir. Ancak, kinoa tohumlarında bin dane ağırlığı, kül, kuru madde, protein ve yağ içeriği açısından farklı sulama düzeylerinde istatistiksel olarak fark olmadığı, yağ asitleri açısındansa sadece eikosenoik asit içeriğinin sulama düzeylerine bağlı olarak istatistiksel anlamda farklılık $(\mathrm{p}<0.05)$ gösterdiği, uygulanan sulama suyu miktarı azaldıkça kinoa tohumlarında bulunan eikosenoik asit içeriğinin arttığı ve en yüksek eikosenoik asit içeriğinin SZ konusunda olduğu belirlenmiştir.

\section{ARTICLE INFO}

Received 07 May 2020

Received in revised form 21 September 2020

Accepted 28 September 2020

\section{Keywords:}

Yield

Stomatal conductivity

Chlorophyll

Protein content

Fatty acids

\section{ABSTRACT}

In this study, the effects of deficit irrigation applications on the vegetative growth and yield quality parameters of the quinoa grown in Mediterranean conditions were determined. The research was conducted in drainage-type lysimeters, filled with sandy loam soil, in 2017 with Titicaca (Q-52) quinoa (Chenopodium quinoa Willd.). In the research, full irrigation (TS), $75 \%, 50$ and $25 \%$ of deficit irrigation (KS75, KS50, KS25) and rainfed (SZ) treatments were tested in randomized blocks design with three replications. Irrigation water was applied to the TS treatment 7-day intervals to bring the soil water content to the field capacity, and the deficit irrigation treatments were irrigated taking into account the specified cut-off rates. At the end of the trial, grain yield, plant height, stomatal conductance varied between 243.0 (SZ) - 295.0 (TS) $\mathrm{kg} \mathrm{da}^{-1}$; 93.5 (SZ) - 103.2 (TS) $\mathrm{cm} ; 252.4$ (SZ) -319.8 (TS) mmol m${ }^{-2} \mathrm{~s}^{-1}$, respectively, and leaf chlorophyll index value varied between 2.8-57.0 during the season. Grain yield, plant height, stomatal conductivity values in irrigation treatments and leaf chlorophyll content values during the season, showed statistically significant differences $(\mathrm{p}<0.01)$. However, there was no statistical difference in irrigation levels in terms of 1000-seed weight, ash, dry matter, protein and oil content. In terms of fatty acids, only the eicosenic acid content differed statistically $(\mathrm{p}<0.05)$ depending on the irrigation levels, and as the amount of applied irrigation water decreased, the eicosanoic in the quinoa seeds increased. The highest eicosenic acid content was determined in SZ treatment. 


\section{Giriş}

Kinoa (Chenopodium quinoa Willd.), ülkemiz için yeni, ancak Güney Amerika'nın yüksek dağlık kesimlerinde asırlardır bilinen ve daha çok kurak ve tuzlu koşullarda yetiştiriciliği yapılan önemli bir tahıl bitkisidir. Bazı uzmanlara göre dünyadaki açlık sorununa çare olabilecek bitkilerden biri olarak görülen kinoanın tahıl ve bakliyat ürünleri gibi insan yiyeceği olarak kullanımı ve ticareti gün geçtikçe artmaktadır (Tan ve Yöndem 2013; Jacobsen ve Stolen 1993). Vitamin, mineral ve antioksidan maddelerce zengin olan kinoa tohumlarının protein içeriği ve kalitesi yaygın olarak kullanılan diğer tahıllara göre daha yüksektir (Koziol 1992).

Kuraklığa toleranslı bir bitki olmakla birlikte kinoanın verimi sulamadan önemli ölçüde etkilenmektedir (Flynn 1990). Çeşitlere bağlı olarak, kinoa tohumları diğer tahıllardan \%10'a kadar daha yüksek yağ içermektedir (Valencia-Chamorro 2016). Peiretti ve ark. (2013), kinoa ve soya fasulyesinin linoleik, oleik ve palmitik yağ asidi içeriklerinin benzer olduğunu bildirmişleridir.

Kinoa verim ve kalitesinin uygulanan sulama suyu miktarına (Yazar ve ark. 2015), sulama suyunun uygulanma sıklığına (Algosaibi ve ark. 2017), farklı sulama sistemlerine (Buckland ve ark. 2019), bitki yoğunluğuna (Wang ve ark. 2020), farklı sulama suyu kalitelerine (Amjad ve ark. 2015) ve farklı çeşitlere (Bertero ve ark. 2004) bağlı olarak değiştiği belirlenmiştir. Ayrıca, \%50 kısıntılı sulama uygulamasında dane veriminin \%36 azaldığ (Hirich ve ark. 2013), dane dolum döneminde iyi sulanan ve su stresi yaşayan farklı kinoa çeşitlerinin dane verimlerinde ve bin dane ağırlıklarında istatistik açıdan farklılık olmadığı (Gamez ve ark. 2019), kinoda stoma iletkenliği ile absisik asit konsantrasyonu arasında negatif ilişki olduğu (Gamez ve ark. 2019) saptanmıştır.

Kinoa bitkisinin kalite özelliklerinden olan protein, yağ ve yağ asidi içeriğinin belirlenmesi ile ilgili çalışmalar daha çok çeşitler arasındaki farklılı̆̆ belirlemek amacıyla yapılmıştır (Marmouzi ve ark. 2015; Präger ve ark. 2018). Buna karş1, kısıntılı sulamayla uygulanan farklı düzeylerdeki su stresi koşullarında kinoa bitkisinin vejetatif gelişme parametreleri ile elde edilen verimin kalite özelliklerinin belirlenmesine yönelik çalışmalar literatürde azdır ve daha çok yüksek bölgeleri, farklı iklimsel özellikleri temsil etmektedir.

$\mathrm{Bu}$ çalışmada, farklı düzeylerdeki sulama uygulamalarının Akdeniz iklimi koşullarında lizimetrede yetiştirilen kinoa bitkisinin verim, bitki boyu, stoma iletkenliği, klorofil içeriği gibi vejetatif parametreler üzerine etkileri ile bitki tohumlarında bulunan protein, yağ ve yağ asitleri içerikleri üzerine etkilerinin belirlenmesi amaçlanmıştır.

\section{Materyal ve Yöntem}

Araştırma, $30^{\circ} 38^{\prime} 30^{\prime \prime}$ E boylamları ve $36^{\circ} 53^{\prime} 15^{\prime \prime} \mathrm{N}$ enlemleri arasında, denizden 54 m yüksekteki Antalya'da 2017 yılında yürütülmüştür. Bölgede Akdeniz iklimi hüküm sürmekte olup yazlar sıcak ve kurak, kışlar 1 lık ve yağışlıdır. Antalya'da yıllık ortalama sicaklık $18.7^{\circ} \mathrm{C}$, en soğuk ay $10.0^{\circ} \mathrm{C}$ ile Ocak ve en sıcak ay ise $28.4^{\circ} \mathrm{C}$ ile Temmuz ayıdır. Yıllık ortalama bağıl nem \%63.2, ortalama toplam yağıŞ $1085.3 \mathrm{~mm}$ ve ortalama toplam buharlaşma $1826.5 \mathrm{~mm}$ 'dir (MGM 2020). Çalışmanın yürütüldügü drenaj tipi lizimetre sistemi, her biri $2 \times 1 \mathrm{~m}$ boyutlu ve $1.8 \mathrm{~m}$ derinliğe sahip, içi ortalama olarak kuru ağırlık esasına göre tarla kapasitesi değeri \%16.7, devamlı solma noktası değeri $\% 9.9$, hacim ağırlı̆̆ $1.5 \mathrm{~g} \mathrm{~cm}^{-3}$ olan kumlu tın bünyeli toprakla doldurulmuş 15 adet beton bölmeden oluşmaktadır. Lizimetre toprakları tuzsuz, orta derecede alkali, çok kireçli özelliğe sahiptir. Araştırmada Akdeniz koşullarına iyi adapte olmuş Titicaca (Q-52) kinoa çeşidi (Lavini ve ark. 2014) kullanılmıştır. Sulama suyunun elektriksel iletkenliği 0.48

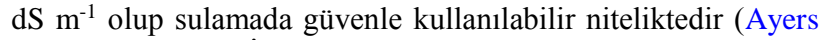
ve Westcot 1985). İşlenen parsellere ekimden önce, $8 \mathrm{~kg} \mathrm{da}^{-1}$ saf $\mathrm{N}, \mathrm{P}, \mathrm{K}$ olacak şekilde kompoze gübre uygulaması yapılarak tüm gübre bir seferde verilmiştir. Kinoa tohumları, $1.5-2 \mathrm{~cm}$ derine, sıra aras1 $50 \mathrm{~cm}$ olacak şekilde (Jacobsen 2003) 15.03.2017 tarihinde (Yazar ve Kaya 2014) elle ekilmiştir. Çıkıştan sonra sıra üzeri mesafe $8-10 \mathrm{~cm}$ olacak şekilde seyreltme yapilarak her bir lizimetre parselinde 34-39 bitki bırakılmıştır. Deneme süresince ot ve zararlılarla mücadele işlemleri sürdürülmüştür.

Araştırma, tesadüf blokları deneme desenine göre 3 tekerrürlü olarak düzenlenmiştir. Araştırmada, tam sulama (TS), sirasiyla TS'nin $\% 75, \% 50$ ve $\% 25$ 'i kadar su uygulanan kisintılı sulama konuları (KS75, KS50, KS25) ve sulama uygulanmayan (SZ) olmak üzere 5 sulama konusu yer almıştır. Topraktaki kullanılabilir suyun yaklaşık \%40'1 tüketildiğinde konulu sulamalara başlanmış, TS konusunda sonraki sulamalar 7 gün ara ile, $90 \mathrm{~cm}$ 'lik profil derinliğindeki eksik su tarla kapasitesine getirilecek biçimde uygulanmıştır (Kaya 2010). KS75, KS50, KS25 konularına ise, tam sulama konusu ile aynı günde, kısıntı oranları dikkate alınarak su uygulanmıştır. Sulamalar damla sulama yöntemiyle gerçekleştirilmiştir. Her bitki sırasına bir lateral boru hattı döşenmiş, $0.2 \mathrm{~m}$ aralıklı, 1 atm işletme basıncında $2 \mathrm{~L} \mathrm{~h}^{-1}$ debili, lateral boruya içten geçik tipte, kendinden basınç düzenleyicili damlatıcılar kullanılmıştır. Gerekli su miktarı hacme dönüştürülerek ölçülü bir şekilde uygulanmış, her lizimetre parselindeki lateral borular ayrı birer vana ile kontrol edilmiştir. Sulamalara kinoanın dane dolum dönemi bitiminde son verilmiştir. Ekimden önceki haftada oluşan toplam 161.9 mm'lik yağış nedeniyle, 0-90 cm'lik profildeki toprak nemi tarla kapasitesinde iken ekim yapılmış, ancak çıkış sağlanana kadar tüm konulara eş miktarda $(2 \mathrm{~mm})$ su uygulanmıştır. Hasat 28.06.2017-01.07.2017 tarihleri arasında yapılmıştır.

Farklı sulama konularında bitkilerin gelişme durumlarını belirlemek için bitki boyu $(\mathrm{cm})$ ölçümleri, her konudaki 4 bitkide deneme süresince ve haftalık olarak yapılmıştır. Bitki yapraklarındaki klorofil içeriği indeksi (CCI) değerleri taşınabilir klorofilmetre aleti (Model CCM-200 plus-Apogee Instruments, Inc., Logan, UT, USA) ile 15.04.2017-20.06.2017 tarihleri arasında, parseldeki 4 adet bitkinin orta yapraklarının yaprak damarı ile yaprak kenarı arasında kalan bölgesinde yapılan okumaların ortalaması olarak belirlenmiştir. Stoma iletkenliği (SC) ise taşınabilir porometre aleti (Model SC-1, Decagon Devices Inc. Pullman WA, USA) ile ekimden 4 hafta sonra başlayarak dane dolum dönemi sonuna kadar tam olgunlaşmış yaprak ortasından, yaprak başına $1 \mathrm{kez}$, parsel başına 3 adet bitki okuması $\left(\mu \mathrm{mol} \mathrm{H}_{2} \mathrm{O} \mathrm{m} \mathrm{m}^{-2} \mathrm{~s}^{-1}\right.$ ) yapılarak belirlenmiştir (Pietragalla ve Pask 2011).

Bitkinin dane verimi, lizimetre parsellerinde, iki bitki sırasının her iki başından birer bitki kenar etkisi olarak ayrıldıktan sonra hasat edilen bitkilerden ölçülen sonuçlar $\mathrm{kg} \mathrm{da}^{-1}$ ' a çevrilerek belirlenmiştir. Her tekerrürde 4 adet 100 'er tohum ağırlığının ortalaması 10 ile çarpılarak bindane ağırlıkları (g) belirlenmiştir (Tan 2011). Kinoa danelerinde toplam kuru madde (\%) ve kül oranı (\%) OKİB (1983)'e; protein oranı (\%) Modifiye Kjeldahl yöntemine (Kaçar ve İnal 2008); yağ oranı (\%) AOAC (2005)'e; yağ asitleri (miristik, palmitik, stearik, 
oleik, linoleik, linolenik, araşidik ve eikosenoik asitler) içeriği (\%) RG (2014)'e göre belirlenmiştir. Araştırmada elde edilen verilerin istatistiksel analizleri SAS $^{\circledR}$ University Edition istatistik programı ve ortalama değerlerin karşılaştırmasında LSD testi kullanılmıştır.

\section{Bulgular ve Tartışma}

\subsection{Yaprak klorofil indeksi ve stoma iletkenliğ $i$}

Deneme süresince farklı sulama konularında yaprak klorofil indeksi (CCI) değerlerinin değişim grafiği Şekil 1'de gösterilmiş, ölçüm tarihlerindeki ortalama CCI değerleri Çizelge 1'de verilmiştir. Yapılan varyans analizi sonuçları dikkate alınarak istatistiki önemlilik durumuna göre deneme konuları arasındaki farklılığ ortaya koyan istatistiki gruplandırmalar da aynı Çizelge üzerinde gösterilmiştir. Yaprağın klorofil içeriği, bitki dokularının fotosentetik yeteneğinin bir göstergesidir (Nageswara Rao ve ark. 2001). Su stresinde yapraklarda klorofil sentezlenmesinin önlemesinden kaynaklanabilen, klorofil içeriğinin azalması (Kramer 1983) CCI değerlerinin stres şiddetinin bir ölçüsü olarak değerlendirilmesine olanak verebilir.

Büyüme mevsimi başlarında hızlı artış gösteren CCI değerleri pik yaptıktan sonra giderek azalma göstermiş, konulu sulamalar uygulandıktan sonra da bu eğilim paralel olarak devam etmiştir (Şekil 1). Deneme konularında CCI'nin zamansal değişiminin önemli $(\mathrm{p}<0.01)$ olduğu; tüm konularda en yüksek CCI değerlerinin 03.05.17 tarihinde (vejetatif gelişim döneminde) ölçüldüğü, daha sonra giderek azaldığı belirlenmiştir (Çizelge 1). Sulama konuları arasında CCI, yalnızca 06.06 .2017 ve 20.06.17 tarihlerinde önemli bulunmuştur. 06.06.2017 günkü istatistiksel fark $(\mathrm{p}<0.05)$, ölçüm gününde bir gün öncesine denk gelen sulamanın dane dolumu başlangıcındaki bitkilerde etkili olması ile açıklanabilir.

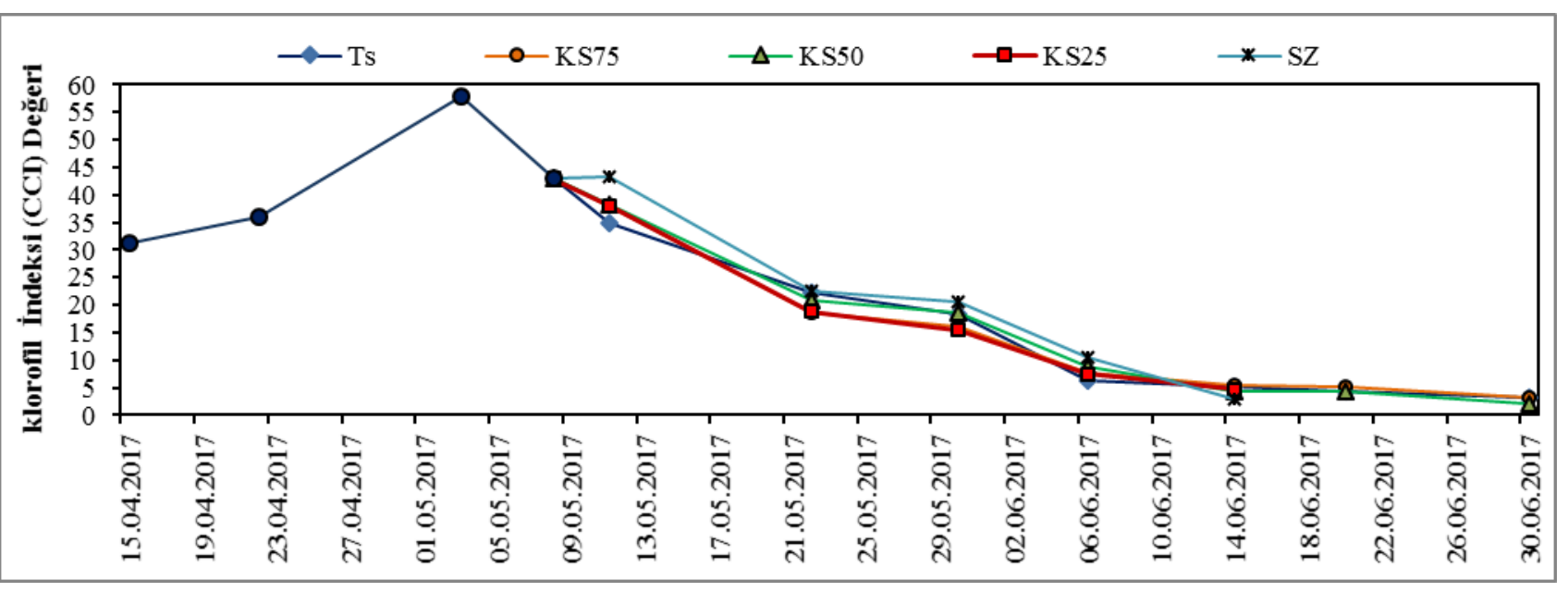

Şekil 1. Kinoa bitkisinde farklı sulama düzeylerinde büyüme mevsimi boyunca klorofil indeksi (CCI) değerlerinin değişimi.

Figure 1. Change in chlorophyll index (CCI) in irrigation treatments during growing season.

Çizelge 1. Bitki gelişim süresince farklı sulama düzeylerinde kinoa bitkisinin yaprak klorofil indeks (CCI) değerlerine ilişkin varyans analizi sonuçları.

Table 1. Variance analysis results regarding leaf chlorophyll index (CCI) in irrigation treatments during crop growth.

\begin{tabular}{|c|c|c|c|c|c|c|c|}
\hline \multirow{2}{*}{ Ölçüm Tarihleri } & \multicolumn{5}{|c|}{ Sulama Konuları } & \multirow{2}{*}{$\mathrm{P}>\mathrm{F}$} & \multirow{2}{*}{ Ölçüm Tarihleri Ort. } \\
\hline & TS & D75 & D50 & $\mathrm{D} 25$ & SZ & & \\
\hline 15.04 .2017 & $30.4^{t} \mathrm{BC}^{\mathrm{m}}$ & $30.4 \mathrm{~B}$ & $30.4 \mathrm{~B}$ & $30.4 \mathrm{~B}$ & $30.4 \mathrm{C}$ & ö.d. & $30.4 \mathrm{D}$ \\
\hline 22.04 .2017 & $33.7 \mathrm{~B}$ & $33.7 \mathrm{~B}$ & $33.7 \mathrm{~B}$ & $33.7 \mathrm{~B}$ & $33.7 \mathrm{C}$ & ö.d. & $33.7 \mathrm{C}$ \\
\hline 03.05 .2017 & $57.0 \mathrm{~A}$ & $57.0 \mathrm{~A}$ & $57.0 \mathrm{~A}$ & $57.0 \mathrm{~A}$ & $57.0 \mathrm{~A}$ & ö.d. & $57.0 \mathrm{~A}$ \\
\hline 08.05 .2017 & $34.2 \mathrm{~B}$ & $34.2 \mathrm{~B}$ & $34.2 \mathrm{~B}$ & $34.2 \mathrm{~B}$ & $34.2 \mathrm{C}$ & ö.d. & $34.2 \mathrm{BC}$ \\
\hline 11.05 .2017 & $34.0 \mathrm{~B}$ & $35.6 \mathrm{~B}$ & $37.5 \mathrm{~B}$ & $37.5 \mathrm{~B}$ & $41.9 \mathrm{~B}$ & ö.d. & $37.3 \mathrm{~B}$ \\
\hline 22.05 .2017 & $23.6 \mathrm{CD}$ & $17.7 \mathrm{C}$ & $21.4 \mathrm{C}$ & $19.3 \mathrm{C}$ & $22.3 \mathrm{D}$ & ö.d. & $20.9 \mathrm{E}$ \\
\hline 30.05 .2017 & $18.4 \mathrm{D}$ & $17.0 \mathrm{C}$ & $18.0 \mathrm{C}$ & $15.6 \mathrm{C}$ & $20.8 \mathrm{D}$ & ö.d. & $18.0 \mathrm{E}$ \\
\hline 06.06 .2017 & $6.1 \mathrm{~Eb}^{\zeta}$ & $7.3 \mathrm{Db}$ & 7.3 Db & $6.9 \mathrm{Db}$ & $10.6 \mathrm{Ea}$ & $*$ & $7.6 \mathrm{~F}$ \\
\hline 14.06 .2017 & $4.9 \mathrm{E}$ & $5.5 \mathrm{D}$ & $4.4 \mathrm{D}$ & $5.2 \mathrm{D}$ & $3.2 \mathrm{EF}$ & ö.d. & 4.7 FG \\
\hline 20.06 .2017 & $4.3 E b$ & $5.1 \mathrm{Da}$ & $4.3 \mathrm{Db}$ & $0.0 \mathrm{Dc}$ & $0.0 \mathrm{Fc}$ & $* *$ & $2.8 \mathrm{G}$ \\
\hline $\mathrm{P}>\mathrm{F}$ & $* *$ & $* *$ & $* *$ & $* *$ & $* *$ & & \\
\hline Sulama Düzeyi Ort. & 24.6 & 24.4 & 24.8 & 24.0 & 25.4 & & \\
\hline Önemlilik & \multicolumn{2}{|c|}{ Ölçüm Tarihi: ** } & \multicolumn{2}{|c|}{ Sulama Konusu: ö.d. } & \multicolumn{3}{|c|}{ Ölçüm Tarihi × Sulama Konusu: ö.d. } \\
\hline
\end{tabular}

$\dagger^{\dagger}$ : İtalik yazılmış her bir değer dokuz farklı bitkiden elde edilen ölçümlerin ortalamasıdır. ${ }^{\zeta}:$ Küçük harfler LSD testine göre p<0.05 önem düzeyinde her bir satır boyunca verilen ortalamaların karşılaştırmasını göstermektedir. ${ }^{\circledR}$ : Büyük harfler LSD testine göre p $<0.05$ önem düzeyinde her bir sütun boyunca verilen ortalamaların karşılaştırmasını göstermektedir. * ve**: sırasıyla $\mathrm{p}<0.05$ ve $\mathrm{p}<0.01$ olasılık düzeyinde önemlidir. öd: İstatistiksel anlamda önemsizdir. 
20.06.17 tarihindeki fark ise $(p<0.01)$ ise SZ ve KS25 konularında yeşil yaprak kalmaması nedeniyle CCI ölçümü yapılamaması dolayısıyla anılan konuların aynı gruba girmeleri, diğer konularınsa ölçüm öncesi iki günde düşen yağıştan etkilenmeleri ile açıklamak olasıdır. Sulama konularının ortalama CCI değerleri arasında istatistiksel farklılık olmaması ise kinoa bitkisinin kuraklığa direncinin yüksek olmasından kaynaklanabilir. Farklı bitki türlerinde kuraklık stresi altında klorofil içeriğinde azalma veya değişmemişlik gözlenmiştir (Rensburg ve Kruger 1994). Stoma iletkenliği (SC) değerlerindeki değişimin grafiksel gösterimi Şekil 2'de, ölçüm tarihlerindeki stoma iletkenliği (SC) değerleri ile yapılan varyans analizi sonuçları dikkate alınarak istatistiki önemlilik durumuna göre deneme konuları arasındaki farklılığı ortaya koyan istatistiksel gruplandırmalar Çizelge 2'de gösterilmiştir. Konulu sulamalara başlandıktan sonra SC değerleri farklılaşmaya başlamış ve genel olarak TS konusundan SZ konusuna doğru giderek azalan bir eğilim göstermiştir (Şekil 2). Ölçüm tarihi, sulama konusu ve ölçüm tarihi $\times$ sulama konusu interaksiyonları arasında istatistiksel farklılıklar $(\mathrm{p}<0.01)$ belirlenmiştir (Çizelge 2). Konulu sulama uygulamaları başladıktan sonra araştırma konularında 11.05.17, 15.05.17, 18.05.17, 07.06.17, 13.06.17 ve 21.06.17 tarihlerinde ölçülen stoma iletkenliği değerleri incelendiğinde SC'nin en yüksek

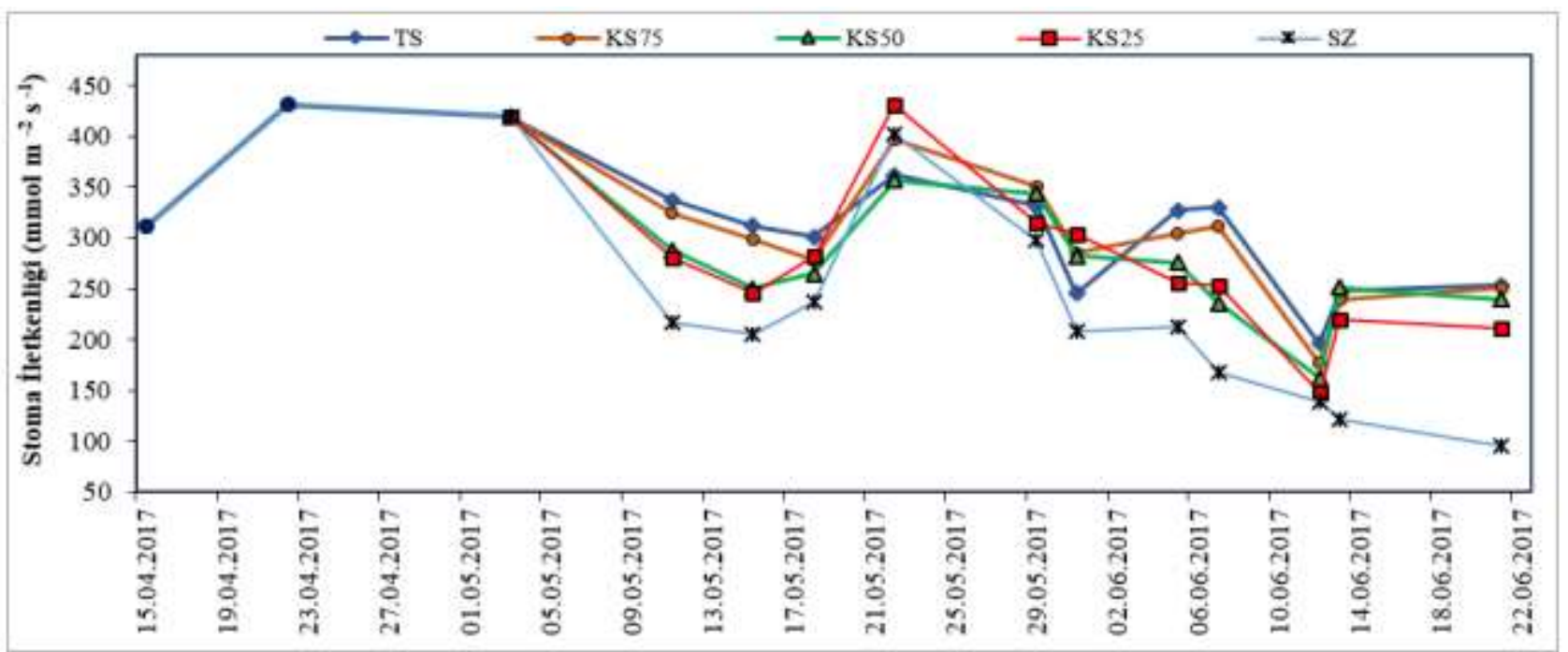

Şekil 2. Farklı sulama düzeylerinde mevsim boyunca kinoa bitkisinde stoma iletkenliği (SC) değerlerinin değişimi.

Figure 2. Change in stomatal conductance in irrigation treatments during growing season.

Çizelge 2. Farklı sulama konularında farklı tarihlerde ölçülen kinoa bitkisinin stoma iletkenliği (SC) $\left(\mathrm{mmol} \mathrm{m} \mathrm{s}^{-2} \mathrm{~s}^{-1}\right)$ değerlerine ilişkin varyans analiz sonuçları.

Table 2. Variance analysis results regarding stomatal conductance $(\mathrm{SC})\left(\mathrm{mmol} \mathrm{m} \mathrm{m}^{-2} \mathrm{~s}^{-1}\right)$ measured in irrigation treatments.

\begin{tabular}{|c|c|c|c|c|c|c|c|}
\hline \multirow{2}{*}{ Ölçüm Tarihleri } & \multicolumn{5}{|c|}{ Sulama Konuları } & \multirow{2}{*}{$P>F$} & \multirow{2}{*}{ Ölçüm Tarihleri Ort. } \\
\hline & TS & KS75 & KS50 & KS25 & SZ & & \\
\hline 15.04 .17 & $363.5^{\dagger} B^{m}$ & $363.5 B C$ & $363.5 B C$ & $363.5 B$ & $363.5 \mathrm{~B}$ & ö.d & $363.5 \mathrm{C}$ \\
\hline 22.04 .17 & $429.1 A$ & $429.1 \mathrm{~A}$ & $429.1 A B$ & $429.1 \mathrm{~A}$ & $429.1 \mathrm{~A}$ & ö.d & $429.1 \mathrm{~A}$ \\
\hline 03.05 .17 & $439.4 \mathrm{~A}$ & 439.4 A & $439.4 \mathrm{~A}$ & $439.4 \mathrm{~A}$ & $439.4 \mathrm{~A}$ & ö.d & $439.4 \mathrm{~A}$ \\
\hline 11.05 .17 & $337.4 B C a^{\zeta}$ & $324.5 C E a b$ & $287.9 \mathrm{DEbc}$ & $279.8 C E c$ & $215.4 \mathrm{DEd}$ & $* *$ & $289.0 \mathrm{E}$ \\
\hline 15.05 .17 & $312.1 B D a$ & $298.5 \mathrm{DFab}$ & $250.6 \mathrm{Ebc}$ & $246.2 E F b c$ & $205.2 \mathrm{DEc}$ & $* *$ & $262.5 \mathrm{~F}$ \\
\hline 18.05.17 & $301.3 C E a$ & $281.0 \mathrm{EGab}$ & $265.0 \mathrm{~Eb}$ & 281.6 CEab & $237.0 C D c$ & $* *$ & $273.2 \mathrm{EF}$ \\
\hline 22.05 .17 & $362.1 B$ & $397.2 A B$ & $357.2 C$ & $431.1 \mathrm{~A}$ & $401.6 A B$ & ö.d & $389.8 \mathrm{~B}$ \\
\hline 29.05 .17 & $331.8 B C$ & $350.3 B D$ & $343.7 C D$ & $315.3 B C$ & $298.3 C$ & ö.d & $327.9 \mathrm{D}$ \\
\hline 31.05 .17 & 245.7 EFab & $285.3 E G a$ & $282.2 \mathrm{DEa}$ & $303.8 C D a$ & $208.4 \mathrm{DEb}$ & $*$ & $265.1 \mathrm{EF}$ \\
\hline 05.06 .17 & $327.4 B C a$ & $304.5 \mathrm{DFab}$ & $276.7 \mathrm{Eac}$ & $256.5 \mathrm{DFbc}$ & $212.9 \mathrm{DEc}$ & $*$ & $275.6 \mathrm{EF}$ \\
\hline 07.06 .17 & $329.7 \mathrm{BCa}$ & 311.3 CEab & $236.1 E b c$ & $252.8 D F a b$ & $167.5 \mathrm{EFC}$ & $* *$ & $259.5 \mathrm{~F}$ \\
\hline 12.06.17 & $196.3 \mathrm{~F}$ & $176.4 \mathrm{H}$ & $162.4 F$ & $147.1 G$ & $138.5 F G$ & ö.d & $164.1 \mathrm{H}$ \\
\hline 13.06.17 & 247.6EFab & $239.6 G a b$ & $251.3 \mathrm{Ea}$ & $219.6 \mathrm{Fb}$ & $121.0 \mathrm{FGc}$ & ** & $215.8 \mathrm{G}$ \\
\hline 21.06 .17 & $253.4 \mathrm{DFa}$ & $250.8 F G a$ & $239.4 E a$ & $210.6 \mathrm{Fa}$ & $95.9 G b$ & $* *$ & $210.0 \mathrm{G}$ \\
\hline $\mathrm{P}>\mathrm{F}$ & $* *$ & $* *$ & $* *$ & $* *$ & ** & & \\
\hline Sulama Konuları Ort. & $319.8 \mathrm{a}$ & $318.0 \mathrm{a}$ & $298.9 \mathrm{~b}$ & $298.3 \mathrm{~b}$ & $252.4 \mathrm{c}$ & & \\
\hline Önemlilik & Ölçüm Tarihi & & ulama Konusu & & $\mathrm{n}$ Tarihi $\times \mathrm{S}$ & $\mathrm{a} \mathrm{Ko}$ & $* *$ \\
\hline
\end{tabular}

${ }_{\dagger}^{\dagger}$ : İtalik yazılmış her bir değer dokuz farklı bitkiden elde edilen ölçümlerin ortalamasıdır. ${ }^{\zeta}:$ Küçük harfler LSD testine göre p<0.05 önem düzeyinde her bir satır boyunca verilen ortalamaların karșılastırmasını göstermektedir. ${ }^{\text {: }}$ : Büyük harfler LSD testine göre $\mathrm{p}<0.05$ önem düzeyinde her bir sütun boyunca verilen ortalamaların

karşılaştırmasını göstermektedir. * ve**: sırasıyla $\mathrm{p}<0.05$ ve $\mathrm{p}<0.01$ olasılık düzeyinde önemlidir. öd: İstatistiksel anlamda önemsizdir. 
olduğu konunun TS konusu olduğu, sulama konuları arasındaki farkların önemli olduğu $(\mathrm{p}<0.01$ ve $\mathrm{p}<0.01)$ görülmektedir. 22.05.17 ve 29.05.17 tarihlerindeki ölçümlerde konular arasında istatistiksel fark bulunmaması ise, söz konusu dönemlerde görülen yağışlardan (toplam $23.5 \mathrm{~mm}$ ) kaynaklanabilir. 12.06.17 tarihindeki ölçümlerde ise konular arasında istatistiksel olarak bir fark olmadığı belirlenmiştir. Ayrıca, kinoa bitkisinde vejetatif gelişim dönemi içinde SC'nin giderek arttığı ancak hasat zamanına doğru ise azaldığı söylenebilir. En yüksek ortalama stoma iletkenliği TS ve KS75 konularında (sırasıyla 319.8 ve $318.0 \mathrm{mmol} \mathrm{m}^{-2} \mathrm{~s}^{-1}$ ) ölçülmüş olup, iki konu istatistiksel anlamda aynı grupta yer almıştır. En düşük ortalama $\mathrm{SC}$ ise, SZ konusunda $\left(252.4 \mathrm{mmol} \mathrm{m} \mathrm{m}^{-2} \mathrm{~s}^{-1}\right)$ meydana gelmiştir. Stomalar, vejetatif yüzeyler arasındaki gaz ve enerji alışverişi konusunda çok önemli rol oynarlar (Berry ve ark. 2010). Kuraklık stresi altındaki bitkiler stomalarını kapatıp, $\mathrm{CO}_{2}$ ve su buharı akışını azaltarak tepki verirler (Yordanov ve Tsonev 2000). Dolayısıyla SC, bitkilerin potansiyel üretkenliğini ve verimini belirleyen anahtar bir parametredir (Horie ve ark. 2006) Stoma iletkenliğinin yüksek olması, bitkinin stres koşuluna karşı dayanımını pozitif yönde etkileyen bir özelliktir. Nitekim Jacobsen ve ark. (2009), kuraklıkla birlikte kinoada SC'nin giderek azaldığını bildirmişlerdir.

\subsection{Verim ve kalite parametreleri}

Deneme konularından elde edilen kinoa dane verimi, bin dane ağırlığı, bitki boyu, kül içeriği, kuru madde, protein ve yağ içerikleri ile varyans analizi sonuçları göz önüne alınarak yapılan LSD testine göre deneme konularının istatistiki gruplandırılmaları Çizelge 3'te verilmiştir. Sulama konuları arasındaki dane verimi farklılıkları istatiksel açıdan $(\mathrm{p}<0.01)$ önemli bulunmuştur (Çizelge 3). En yüksek dane verimi 295.0 $\mathrm{kg} \mathrm{da}^{-1}$ ile TS konusundan, en düşük dane verimi $243.0 \mathrm{~kg} \mathrm{da}^{-1}$ ile SZ konusundan elde edilmiştir. KS75 konusu bir ara grup oluştururken KS25 ve SZ konuları son gruba girmişlerdir. Bu sonuçlara göre kinoa bitkisinde su kısıntısının dane verimi üzerindeki etkisinin önemli olduğu, tam sulamanın \%25'i düzeyinde kısıntılı sulama yapmanın kinoa dane veriminde istatistiksel açıdan fark yaratmadığı söylenebilir. Steduto ve ark. (2012), kinoa dane verimini $85-450 \mathrm{~kg} \mathrm{da}^{-1}$ olduğunu ifade etmişlerdir. Geerts ve ark. (2008) ise, iyi planlanmış bir kısıntılı sulama ile kinoadan $120-200 \quad \mathrm{~kg} \mathrm{da}^{-1}$ arasinda verim sağlanabileceğini bildirmişlerdir. Türkiye'de yapılan bazı çalışmalarda ise $169.1-400.3 \mathrm{~kg} \mathrm{da}^{-1}$ arası kinoa verimi elde edilmiştir (Kaya 2010; Geren ve ark. 2014; Kır ve Temel 2017). Tam sulama ve farklı düzeylerde kısıntı uygulanan konulardan elde edilen dane verimi farklılıklarının, araştırmalarda kullanılan çeşitlerin genetik yapılarından ve iklimsel koşullara olan tepkilerinin farklılığından kaynaklanabileceği söylenebilir.
Gelişme mevsimi boyunca bitki boyu değişimi Şekil 3'te verilmiştir. Kinoa bitkisinin erken vejetatif gelişim döneminin ilk ayında boy gelişimi çok yavaş olup, bitki boyu en hızlı geliş̧imini geç vejetatif dönemde göstermiş, boy artış1 çiçeklenme dönemine kadar devam etmiştir (Şekil 3). Sulama konuları arasında mevsim sonundaki bitki boyu istatistiksel açıdan $\mathrm{p}<0.01$ düzeyinde önemli bulunmuştur. Kısınt1 miktarıyla orantılı bir azalma göstererek mevsim sonundaki en yüksek boy TS konusunda $(103.2 \mathrm{~cm})$, en düşük boy $\mathrm{SZ}$ konusunda $(93.5 \mathrm{~cm})$ belirlenmiştir (Çizelge 3). Elde edilen sonuçlar diğer çalışmalardaki bulguları (Kaya 2010) desteklemektedir.

Sulama konuları arasında kinoanın bin dane ağırlıkları 3.1-3.4 g arasında değişmiş, konular arasındaki farklılıklar istatistiksel olarak önemsiz bulunmuş (Çizelge 3), Kaya (2010) benzer sonuçlara ulaşmıştır. Geren ve ark. (2014) ise, ekim zamanın bin dane ağırlığı üzerindeki etkisinin önemli olduğunu, en yüksek bin dane ağırlığının (3.5 g) 1 Mart'ta yapılan ekimde elde edildiğini belirtmişlerdir.

Kül, kuru madde, protein ve yağ içeriği yönünden sulama düzeyleri arasındaki farklar istatistiksel açıdan önemli bulunmamıştır (Çizelge 3). Bhargava ve ark. (2006), kinoa kül içeriğinin (\%3.4) çeltik ve buğdaya göre daha yüksek olduğunu bildirmişlerdir. Talebnejad ve Sepaskhah (2015), farklı tuzlu taban suyu derinlikleri ve sulama suyu tuzluluklarının kinoa danelerindeki protein içeriğinde istatistiksel olarak farklılık oluşturmadığını belirlemişlerdir.

Deneme konularından elde edilen kinoanın yağ asitleri (miristik, palmitik, stearik, oleik, linoleik, araşidik ve eikosenoik) kompozisyonu ile varyans analizi sonuçları göz önüne alınarak yapılan LSD testine göre deneme konularının istatistiki gruplandırılmaları Çizelge 4'de verilmiştir. Kinoa danelerinin miristik, palmitik, stearik, oleik, linoleik, linolenik ve araşidik asit içeriği (\%) yönünden sulama düzeyleri arasında farkların istatistiksel açıdan önemli olmadığı, başka bir değişle, su stresinin kinoa danelerinde sözkonusu asitlerin içeriğini etkilemediği belirlenmiştir. Literatürde kinoa yağının, yăg asitleri kompozisyonu üzerine sulama düzeylerinin etkisine ilişkin pek fazla sonuç bulunmamaktadır. Kinoanın yağ asidi içeriği, soya yağına benzemektedir (Valencia-Chamorro 2016). Bununla beraber kinoa daneleri yaklaşık olarak \%6-8 oranında toplam lipit içerirken, bu lipitlerin de büyük bir çoğunluğunu linoleik (\%52), linolenik ve oleik asit gibi esansiyel yağ asitleri oluşturmaktadır (Park ve Morita 2004). Koziol (1992), Ruales ve Nair (1993) ve Repo-Carrasco ve ark. (2003), kinoa bitkisinde oleik asit içeriğini sırasılla \%23.3, 24.8 ve 26.0 ; kinoada yüksek oranda bulunan yă asitlerinden biri olan linoleik asit içeriğini sırasıyla \%53.1, 52.3 ve 50.2 ; linolenik asit içeriğini sırasıyla $6.2,3.9$ ve 4.8 olarak saptamışlardır.

Çizelge 3. Deneme konularından elde edilen kinoa dane verimi, bin dane ağırlığı, bitki boyu, kül içeriği, kuru madde içeriği değerlerine ilişkin varyans analizi sonuçları.

Table 3. Variance analysis results regarding seed yield, 1000-seed weight, plant height, ash, and dry matter.

\begin{tabular}{|c|c|c|c|c|c|c|c|}
\hline Sulama Konuları & $\begin{array}{l}\text { Dane Verimi } \\
\left(\mathrm{kg} \mathrm{da}^{-1}\right)\end{array}$ & $\begin{array}{c}\text { Bin Dane Ağırlığ1 } \\
(\mathrm{g})\end{array}$ & $\begin{array}{l}\text { Bitki Boyu } \\
(\mathrm{cm})\end{array}$ & $\begin{array}{c}\text { Kül İçeriği } \\
(\%)\end{array}$ & $\begin{array}{c}\text { Kuru Madde İçeriği } \\
(\%)\end{array}$ & $\begin{array}{c}\text { Protein İçeriği } \\
(\%)\end{array}$ & $\begin{array}{c}\text { Yağ İçeriği } \\
(\%)\end{array}$ \\
\hline $\mathrm{TS}$ & $295.2 \mathrm{a}^{\zeta}$ & 3.3 & $103.2 \mathrm{a}$ & 5.79 & 91.33 & 10.32 & 5.10 \\
\hline KS75 & $284.2 \mathrm{ab}$ & 3.4 & $100.0 \mathrm{ab}$ & 4.97 & 91.59 & 10.26 & 5.14 \\
\hline KS50 & $273.6 \mathrm{~b}$ & 3.3 & $96.3 \mathrm{bc}$ & 5.30 & 90.99 & 10.46 & 5.00 \\
\hline KS25 & $246.5 \mathrm{c}$ & 3.1 & $95.2 \mathrm{c}$ & 5.68 & 91.43 & 10.00 & 5.20 \\
\hline $\mathrm{SZ}$ & $243.0 \mathrm{c}$ & 3.3 & $93.5 \mathrm{c}$ & 5.04 & 91.65 & 10.14 & 5.44 \\
\hline Önemlilik & $* *$ & ö.d. & $* *$ & ö.d. & ö.d. & ö.d. & ö.d. \\
\hline
\end{tabular}




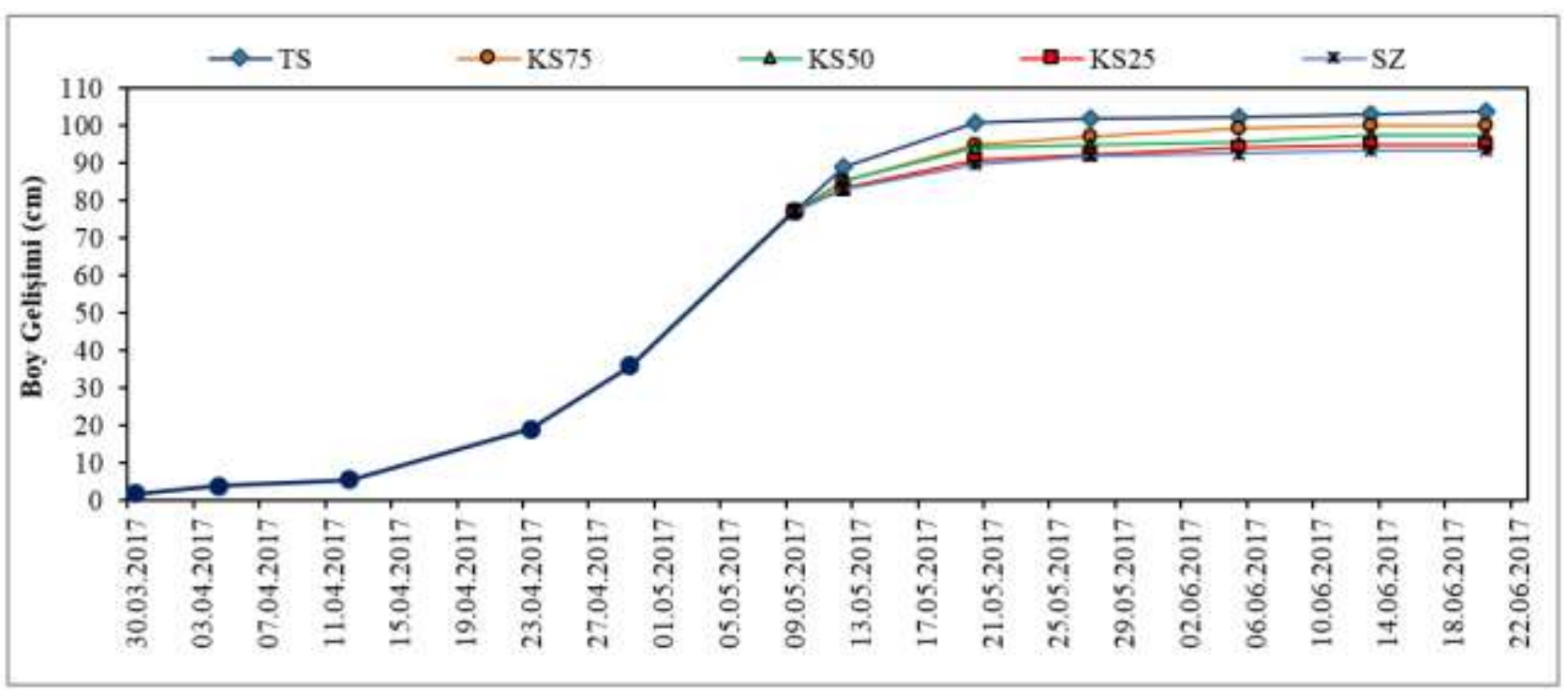

Şekil 3. Farklı sulama düzeylerinde mevsim boyunca kinoa bitkisinin ortalama boy $(\mathrm{cm})$ gelişimi.

Figure 3. Plant height in irrigation treatments during growing season.

Çizelge 4. Deneme konularından elde edilen kinoanın yağ asitleri kompozisyonuna ilişkin varyans analizi sonuçları.

Table 4. Variance analysis results regarding fatty acid composition of quinoa seeds.

\begin{tabular}{|c|c|c|c|c|c|c|c|c|}
\hline $\begin{array}{c}\text { Sulama } \\
\text { Konuları }\end{array}$ & $\begin{array}{c}\text { Miristik Asit } \\
(\%)\end{array}$ & $\begin{array}{l}\text { Palmitik } \\
\text { Asit (\%) }\end{array}$ & $\begin{array}{c}\text { Stearik Asit } \\
(\%)\end{array}$ & $\begin{array}{c}\text { Oleik Asit } \\
(\%)\end{array}$ & $\begin{array}{c}\text { Linoleik Asit } \\
(\%)\end{array}$ & $\begin{array}{c}\text { Linolenik } \\
\text { Asit (\%) }\end{array}$ & $\begin{array}{c}\text { Araşidik Asit } \\
(\%)\end{array}$ & $\begin{array}{c}\text { Eikosenoik } \\
\text { Asit (\%) }\end{array}$ \\
\hline TS & 0.28 & 9.63 & 0.53 & 22.60 & 59.93 & 5.30 & 0.37 & $1.38 \mathrm{a}^{\zeta}$ \\
\hline KS75 & 0.28 & 9.56 & 0.61 & 22.71 & 59.73 & 5.38 & 0.37 & $1.40 \mathrm{ab}$ \\
\hline KS50 & 0.28 & 9.50 & 0.57 & 22.46 & 60.00 & 5.42 & 0.36 & $1.41 \mathrm{abc}$ \\
\hline KS25 & 0.27 & 9.44 & 0.64 & 23.40 & 59.24 & 5.18 & 0.40 & $1.44 \mathrm{bc}$ \\
\hline SZ & 0.30 & 9.36 & 0.58 & 22.81 & 59.75 & 5.37 & 0.36 & $1.45 \mathrm{c}$ \\
\hline Önemlilik & ö.d. & ö.d. & ö.d. & ö.d. & ö.d. & ö.d. & ö.d. & * \\
\hline
\end{tabular}

önemlidir ve öd: istatistiksel anlamda önemsizdir.

Kinoa danelerinin eikosenoik asit içeriği yönünden sulama konuları arasındaki farklar ise istatistiksel açıdan önemli $(\mathrm{p}<0.05)$ bulunmuştur (Çizelge 4$)$. En yüksek eikosenoik asit içeriği SZ (\%1.45) konusunda en düşük eikosenoik içeriği ise TS (\%1.38) konusunda belirlenmiş, su stresi arttıkça kinoa danelerinde eikosenoik asit içeriği artış göstermiştir. Yağ asitleri kompozisyonu sabit olmayıp bitki cinsi ve ekolojik koşullar ile ekim zamanı gibi çevresel ve genetik etkenlere göre değişiklik gösterebilmektedir (Cherry ve ark. 1985). Eikosenoik asit hariç tutulursa kinoanın yağ asitleri içeriğinin su stresi koşullarında değişmemesi, kinoanın besleyici özelliklerinin ve su stresine dayanıklılığının bir göstergesi olarak yorumlanabilir. Ancak bu durum, konuların mevsim boyunca düşen önemli miktardaki yağıştan etkilenmeleri nedeniyle ET düzeyleri arasındaki farklılığın nispeten düşük düzeyde kalmasından da ileri gelebilir.

\section{Sonuçlar}

Akdeniz Bölgesinde, kısıtlı sulama uygulamalarının kinoanın vejetatif gelişim ve verim kalitesi üzerine etkilerinin belirlenmesinin amaçlandığı bu çalışmada, sulama konularında dane verimi $243.0-295.2 \mathrm{~kg} \mathrm{da}^{-1}$ bitki boy gelişimi 93.5-103.2 $\mathrm{cm}$, stoma iletkenliği (SC) değerleri 252.4-319.8 mmol m $\mathrm{m} \mathrm{s}^{-1}$, ve mevsim boyunca klorofil içeriği indeksi (CCI) değeri 2.8-57.0 arasında değişmiş, sulama konular arasında istatistiksel açıdan önemli farklılıklar gözlenmiştir. SC değerlerinin en yüksek seviyede olduğu dönemin vejetatif gelişim dönemi, en yüksek olduğu konunun TS olduğu saptanmıştır. Kinoa bitkisinde farklı sulama konularının; danelerdeki protein, yağ, kül ve kuru madde içeriği üzerinde istatistiksel açıdan önemli farklar yaratmadığ 1 belirlenmiştir. İncelenen yağ asitleri içerisinde, yalnızca eikosenoik asit miktarı istatistiksel açıdan $(\mathrm{p}<0.05)$ farklı sulama düzeylerinden etkilenmiştir. Su stresinin kinoa danelerinde eikosenoik asit oranını arttırdığı sonucuna varılmıştır. Kinoa bitkisinin stoma iletkenliğinin yüksek düzeyde sürdürülebilmesi ve dolayısıyla potansiyel verimliliğini artırmak için tam sulama düzeyinde sulanması önerilebilir.

\section{Teşekkür}

$\mathrm{Bu}$ çalışma Akdeniz Üniversitesi Bilimsel Araştırma Projeleri Koordinasyon Birimi tarafindan (Proje No: FYL-20172365) desteklenmiştir ve söz konusu projeden üretilen 2 . yayındır.

\section{Kaynaklar}

Algosaibi AM, Badran AE, Almadini AM, El-Garawany MM (2017) The effect of irrigation intervals on the growth and yield of quinoa crop and its components. Journal of Agricultural Science 9(9): 182191.

Amjad M, Akhtar SS, Yang A, Akhtar J, Jacobsen SE (2015) Antioxidative response of quinoa exposed to 1so-osmotic, ionic and 
non-1onic salt stress. Journal of Agronomy and Crop Science 201: 452-560.

AOAC (2005) Official methods of analysis of AOAC international (Ed. William Horwitz), Association Official Analytical Chemists. Washington DC, USA.

Ayers AS, Westcot DW (1985) Water quality for agriculture. FAO Irrigation and Drainage. Paper 20, Rome.

Berry JA, Beerling DJ, Franks, PJ (2010). Stomata: Key Players in the Earth System, Past and Present. Current Opinion in Plant Biology (13): 233-240.

Bertero HD, La Vega AJ De, Correa G, Jacobsen SE, Mujica A (2004) Genotype and genotype-by-environment interaction effects for grain yield and grain size of quinoa (Chenopodium quinoa Willd.) as revealed by pattern analysis of international multi-environment trials. Field Crops Research 89: 299-318.

Bhargava A, Shukla S, Ohri D (2006) Chenopodium quinoa-An Indian Perspective. Industrial Crops and Products 23: 73-87.

Buckland KR, Creech JE, Cardon GE, Monaco TA, Reeve JR (2019) Quinoa response to line-source sprinkler irrigation. Journal of Crop Improvement 5(33): 649-668.

Cherry JH, Bishop L, Hasegawa PM (1985) Differences in fatty acid composition of soybean seed produced in northern and southern areas of the USA. Phytochemistry 24(2): 237-241.

Flynn RO (1990) Growth characteristics of quinoa and yield response to increase soil water deficit. Ms Thesis, The University of Colorado State, Fort Collins, U.S.A.

Gamez AL, Soba D, Zamarreño ÁM, García-Mina JM, Aranjuelo I, Morales F (2019) Effect of water stress during grain filling on yield, quality and physiological traits of illpa and rainbow quinoa (Chenopodium quinoa willd.) cultivars. Plants 8(6): 173.

Geerts S, Raes D, Garcia M, Vacher J, Mamani R, Mendoza J, Huanca R, Morales B, Miranda R, Cusicanqui J, Taboada C (2008) Introducing deficit irrigation to stabilize yields of quinoa (Chenopodium quinoa Willd.). European Journal of Agronomy 28: 427-436.

Geren H, Kavut YT, Topçu GD, Ekren S, İştipliler D (2014) Akdeniz iklimi koşullarında yetiştirilen kinoa (chenopodium quinoa willd.)' da farklı ekim zamanlarının tane verimi ve bazı verim unsurlarına etkileri. Ege Üniversitesi Ziraat Fakültesi Dergisi 51(3): 297-305.

Hirich A, Choukr-Allah R, Jacobsen SE (2014) The combined effect of deficit irrigation by treated wastewater and organic amendment on quinoa (Chenopodium quinoa Willd.) productivity. Desalination and Water Treatment 52(10): 2208-2213.

Horie T, Matsuura S, Takai T, Kuwasaki K, Ohsumi A, Shiraiwa T (2006) Genotypic Difference in Canopy Diffusive Conductance Measured by a New Remote-Sensing Method and Its Association with the Difference in Rice Yield Potential. Plant, Cell and Environment (29): 653-660.

Jacobsen SE, Stolen O (1993) Quinoa-morphology and phenology and prospects for its production as a new crop in Europe. Eurapean Journal Agronomy 2: 19-29.

Jacobsen SE (2003) The worldwide potential for quinoa (Chenopodium quinoa Willd.). Food Reviews International, 19: 167-177.

Jacobsen SE, Liu F, Jensen CR (2009) Does root-sourced ABA play a role for regulation of stomata under drought in quinoa (Chenopodium quinoa Willd.). Scientia Horticulturae 122: 281-287.

Kaçar B, İnal A (2008) Bitki analizleri. Nobel Yayın No: 1241.

Kaya Ç (2010) Akdeniz bölgesinde damla sistemiyle tatlı ve tuzlu su kullanılarak uygulanan farklı sulama stratejilerinin quinoa bitkisinin verimiyle toprakta tuz birikimine etkileri ve saltmed modelinin test edilmesi. Çukurova Üniversitesi Fen Bilimleri Enstitüsü Tarımsal Yapılar ve Sulama Anabilim Dalı Yüksek Lisans Tezi, Adana.
Kır AE, Temel S (2017) Sulu koşullarda farklı kinoa (chenopodium quinoa willd.) genotiplerinin tohum verimi ile bazı tarımsal özelliklerinin belirlenmesi. Iğdır Üniversitesi Fen Bilimleri Enstitüsü Dergisi 7(1): 353-361.

Koziol MJ (1992) Chemical composition and nutritional evaluation of quinoa (Chenopodium quinoa Willd.). Journal Food Composition and Analysis 5: 35-68.

Kramer PJ (1983) Water relations of plants. Academic Press, New York, pp. 120-145.

Lavini A, Pulvento C, D’andria R, Riccardi M, Choukr-Allah R, Belhabib O, Yaza, A, Ince Kaya Ç, Sezen SM, Qadir M, Jacobsen SE (2014) Quinoa's potential in the Mediterranean Region. Journal of Agronomy and Crop Science 200(5): 344-360.

Marmouzi I, Madani N El, Charrouf Z, Cherrah Y, Abbes Faouzi MY El (2015) Proximate analysis, fatty acids and mineral composition of processed Moroccan Chenopodium quinoa Willd. and antioxidant properties according to the polarity. Phytotherapie 13: $110-117$.

MGM (2020) T.C Tarım ve Orman Bakanlığı, Meteoroloji Genel Müdürlüğü Antalya iline ait genel istatistik verileri https://www.mgm.gov.tr/veridegerlendirme/il-ve-ilceleristatistik.aspx?m=ANTALYA. Erişim 02 Mayıs 2020.

Nageswara Rao RC, Talwar HS, Wright GC (2001) Rapid assessment of specific leaf area and leaf nitrogen in peanut (Arachis hypogaea L.) using chlorophyll meter. Journal of Agronomy and Crop Science 186: $175-182$.

OKİB (1983) Gıda maddeleri muayene ve analiz yöntemleri. T.C. Orman ve Köy İşleri Bakanlığı, Gıda İşleri Genel Müdürlüğü, Genel Yayın No: 65, Ankara.

Park HS, Morita N (2004) Changes of bound lipids and composition of fatty acids in germination of quinoa seeds. Food Science and Technology Research 10(3): 303-306.

Peiretti PG, Gai F, Tassone S (2013) Fatty acid profile and nutritive value of quinoa (Chenopodium quinoa Willd.) seeds and plants at different growth stages. Animal Feed Science and Technology 183: 56-61.

Pietragalla J, Pask A (2011) Stomatal conductance. In: Pask A, Pietragalla J, Mullan D, Reynolds M. (eds), Wheat physiological breeding II: A field guide to wheat phenotyping. CIMMYT, pp. 1517.

Präger A, Munz S, Nkebiwe PM, Mast B, Graeff-Hönninger S (2018) Yield and quality characteristics of different quinoa (Chenopodium quinoa willd.) cultivars grown under field conditions in southwestern Germany. Agronomy 8(10): 197.

Rensburg LV, Kruger GHJ (1994) Evaluation of components of oxidative stress metabolism for use in selection of drought tolerant cultivars of Nicotiana tabacum L. Journal of Plant Physiology 143: $730-737$.

Repo-Carrasco R, Espinoza C, Jacobsen SE (2003) Nutritional value and use of the Andean crops quinoa (Chenopodium quinoa) and kañiwa (Chenopodium pallidicaule). Food Reviews International 19(1-2): 179-189.

RG (2014) Türk gıda kodeksi zeytinyağı ve prina yağı tebliği, Tebliğ No. 2014/53, Resmi Gazete, say1: 29181.

Ruales J, Nair BM (1993) Content of fat, vitamins and minerals in quinoa (Chenopodium quinoa, Willd) seeds. Food Chemistry 48(2): 131-136.

Steduto P, Hsiao CT, Ferers E, Raes D (2012) Crop yield response to water. FAO İrigation and Drainage, Paper 66, Rome.

Talebnejad R, Sepaskhah AR (2015) Effect of different saline ground water depths and irrigation water salinities on yield and water use of quinoa in lysimeter. Agricultural Water Management 148: 177188 . 
Tan AS (2011) Bazı susam cesitlerinin menemen kosullarında performansları. Anadolu Journal of Agean Agricultural Research Institute 21(2): 11-28.

Tan M, Yöndem Z (2013) İnsan ve hayvan beslenmesinde yeni bir bitki: kinoa (Chenopodium quinoa Willd.). Alınteri 25(B): 62-66.

Valencia-Chamorro SA (2016) Quinoa: Overview. In: Wrigley C, Corke H, Seetharaman K, Faubion J (eds), Encyclopedia of Food Grains (Second Edition). Academic Press, Oxford, pp. 341-348.

Wang N, Wang F, Shock CC, Meng C, Qiao L (2020) Effects of management practices on quinoa growth, seed yield, and quality. Agronomy 10(445): 1-15.
Yazar A, Kaya Ci் (2014) A new crop for salt affected and dry agricultural areas of Turkey: quinoa (Chenopodium quinoa Willd.). Turkish Journal of Agricultural and Natural Sciences, Special Issue, 2: $1440-1446$.

Yazar A, Incekaya Ç, Sezen SM, Jacobsen SE (2015) Saline water irrigation of quinoa (Chenopodium quinoa) under Mediterranean conditions. Crop and Pasture Science 66: 993-1002.

Yordanov I, Velikova V, Tsonev T (2000) Plant responses to drought, acclimation and stress tolerance. Photosynthetica 38: 171-186. 